\title{
Marginalisation of Off-grid Energy Sector in Sri Lanka: What Lessons could be Learnt?
}

Gopal K. Sarangi a , D. Pugazenthi ${ }^{b^{*}}$, Arabinda Mishra ${ }^{\mathrm{c}}$, Debajit Palit ${ }^{\mathrm{d}}$, Subhes C Bhattacharyya e

a Assistant Professor, Department of Policy Studies, TERI School of Advanced

Studies, New Delhi 110070 gopal.sarangi@teriuniversity.ac.in

${ }^{b *}$ Senior Programme Officer, Ashden India Collective, New Delhi 110020

jayan2pugaz@gmail.com,pd@ashdenindia.org

c Senior Social Scientist, Livelihoods, ICIMOD, Kathmandu 3226

Arabinda.Mishra@icimod.org

d Associate Director, Social Transformation, TERI, New Delhi 110003

debajitp@teri.res.in

e Professor, Institute of Energy and Sustainable Development, De Montfort

University,Leicester subhesb@dmu.ac.uk

This paper has been accepted for publication in Environment, Development and Sustainability (a Springer Journal). This is the pre-publication version of the paper, which is made available as per open access requirements of the funding agency.

The final citation will be available in due course but meanwhile it can be cited as follows:

Sarangi, GK, D Pugazenthi, A Mishra, D Palit and SC Bhattacharyya, 2019, Marginalisation of Off-grid Energy Sector in Sri Lanka: What Lessons could be Learnt? Environment, Development and Sustainablity, (in press). 


\title{
Marginalisation of Off-grid Energy Sector in Sri Lanka: What Lessons could be Learnt?
}

\begin{abstract}
Renewable energy based off-grid projects have played a crucial role in Sri Lanka's universal electrification effort. The paper in this context unravels two crucial and quite interrelated aspects of decentralised off-grid energy development in the country; i) to critically analyse the off-grid electricity sector development and assess its contribution to the universal electrification in the country, and ii) to examine the current challenges associated with the off-grid sector in the larger context of massive grid expansion. A mix of quantitative and qualitative research methods is employed as an analytical tool. The paper brings out several policy relevant findings. Strategic policy interventions coupled with targeted policy goals, robust community centric interventions, well designed credit systems, and well-structured capacity building initiatives are identified to be key leveraging points for success of off-grid micro-hydro projects. The techno-economic analysis of existing micro-hydro project reveals there exist opportunity for more productive use of such projects. Grid interconnection of off-grid energy projects is a major emerging challenge involving a whole gamut of technical, legal, regulatory, financial and social issues. Interestingly, the intensity of these challenges differs across ownership types.
\end{abstract}

Key words: off-grid electrification, micro-hydro, Sri Lanka, grid-interconnection

\section{Introduction}

Sri Lanka is an island nation covering a land area of 65,610 sq. km, with a population around 21 million. The country stands ahead of other South Asian countries in many development indicators. The country is rated as a low medium income country by the World Bank with GDP per capita of about 4073 USD in 2017, sustaining a growth rate of $5.8 \%$ in during 2010- 2017 (World Bank, 2019). About $85 \%$ of Sri Lankans continues to live in rural areas and close to one-third of population are employed in the primary sector. Energy occupies a vital place in the socio-economic development map of the country. Provisioning of electricity has been prioritised at all levels of administrative and political agenda-setting in the country (Wickramasinghe, 2013). Latest statistics 
unfold that electricity demand is projected to grow on an average at $6.5 \%$ per year (ADB. 2015). Several international agencies such as World Bank, Asian Development Bank (ADB), Swedish International Development Cooperation Agency (SIDA), Kuwait Fund, and Japan International Cooperation Agency (JICA) have contributed varyingly to the country's effort to provide modern energy to all. Most recent thrust has been on the promotion of renewables in the country. Energy mix figures indicate that close to $9 \%$ of total electricity generation is drawn from renewables.

Sri Lanka, unlike other South Asian countries, has made a commendable progress in electrification rates over the last decade or so. According to latest available statistics, Sri Lanka has already achieved a grid connectivity of $98 \%$ and the remaining areas are electrified through various off-grid electrification systems, largely through micro-hydro based mini-grids and solar home systems (SHSs). The success of the electrification rates is often attributed to the factors such as political motive and willingness manifested through clear policy statements (Palit and Chaurey, 2011), active participation of donor agencies and strategic interventions by the government authorities as well as non-state actors such as NGOs and several forums and associations (World Bank, 2006; Nieusma, 2007; Holland, 2010). While the focus has been biased towards grid-based electrification systems like many other countries with diminishing interest in the off-grid systems (Wickramasinghe, 2013; Salih, 2012), nevertheless the role of off-grid energy systems cannot be undermined (Flavin, 2006; PUCSL, 2012). In fact, various off-grid energy programmes implemented in the country such as 'Energy Service Delivery (ESD) and Renewable Energy for Rural Economic Development (RERED) programmes have significantly contributed to the electrification of the country. Moreover, Public Utilities Commission of Sri Lanka (PUCSL), the electricity regulator of the country, has specifically demarcated about 1000 left-over villages to be electrified through off-grid systems (PUCSL, 2013). Interest in the off-grid energy systems has again been revived as the grid supplied electricity is grappling with the issue of reliability and quality of power.

In this context, it would be analytically interesting to study the role played by off-grid electrification options in the country as well as to see the challenges associated with the process of transitioning to a grid-based electrification system. In addition, off-grid and grid complementarity issue, an emerging issue world-wide, technical and financial complexities associated with the process of net metering, and economic loss due to undersized off-grid projects have not been adequately covered in the existing scholarly research. The paper in this context unravels two crucial aspects related to decentralised off-grid energy development in Sri Lanka, quite connected to each other; i) to critically assess and understand contribution of off-grid energy sector to the electrification effort of 
the country, and ii) to examine the current challenges associated with the off-grid sector in the larger context of massive grid expansion. Experiences gained in Sri Lanka could go a long way in designing and shaping of off-grid electrification strategies of not only South Asian countries, one of the least electrified pockets globally, but also of several other countries in Asia and Africa.

Though solar home systems constitute an important off-grid electrification technology option, the scope of the paper is limited to the detailed assessment of village micro-hydro systems, one of the largest off-grid electrification systems of the country. It is primarily done to approach the research questions in a more systematic and focussed manner. In addition, given that there exist a whole lot of technical, regulatory and financial issues with the grid-interconnection of mini-grids, it merits to lay emphasis on the mini-grids as the focus of the study. These community-based village hydro systems are mainly providing lighting requirements and entertainment loads, with limited. provisioning of productive and enterprising loads like tea processing, cinnamon plantation and grinding. More than $85 \%$ of the installed village micro hydro power projects are of capacity range less than $15 \mathrm{~kW}$.

The paper is organised as follows. Section 2 spells out the methodological approach of the paper. Section 3 offers an overview of the off-grid energy sector development in the country. Section 4 presents the policy and institutional framework governing the off-grid energy sector. Key operational features of the sector are discussed in the Section 5. A detail techno-economic assessment of a village micro-hydro project is presented in the Section 6. The final section concludes the paper.

\section{Study design and methodology}

The paper builds on the mixed method research design to realise the stated objectives of the study. Both qualitative and quantitative research techniques are employed to better comprehend and develop an in-depth understanding of the various dimensions of off-grid energy sector development in Sri Lanka. While qualitative research approach makes use of various qualitative research techniques such as research interviews, focus group discussion (FGDs), and direct observation to understand the complex dimensions and processes of off-grid energy sector development in the country, quantitative research techniques aid in understanding the techno-economic feasibility of a micro-hydro project. A weeklong visit was conducted to Sri Lanka to collate and gather the required set of data and information. A purposive sampling method ${ }^{1}$ was chosen to identify relevant

\footnotetext{
${ }^{1}$ Purposive sampling method is a non-probability sampling method and it occurs when elements selected for the sample are chosen by the researcher based on the availability of sample.
} 
stakeholders having knowledge and wisdom in the field of off-grid energy sector in Sri Lanka. Dates and timing of stakeholder interviews were fixed beforehand with key stakeholders engaged either directly or indirectly in the development of off-grid energy sector in the country. Data and information were gathered in three different phases of field visits. First set of information gathering was carried out by administering a semi-structured questionnaire to an already identified set of stakeholders engaged in various capacities of off-grid energy sector development in the country, largely at the national scale with central offices in Colombo and few provincial offices. The second phase of information gathering was done by visiting a micro-hydro project site named "Maha Dola Village Micro Hydro Power Project", located in Kavittikanda village in Ayagama divisional secretariat area of Ratnapura district. With the total capacity of $7.5 \mathrm{~kW}$, the project is electrifying about 37 households. Data and information gathering at the field sites involved administering semistructured questionnaires to key stakeholders such as project consultants, project developers, president of the project, members of village energy committee and a selected group of beneficiaries (almost $30 \%$ of the total beneficiaries) to elicit relevant information on key aspects of project operation and management. This was supplemented by information collated through as transect walk and direct observations, and visual mappings. Third and final round of interviews were conducted again with stakeholders engaged in the policy making and planning of these interventions to corroborate with the evidences gathered at the field sites. Finally, this information was supplemented with the information gathered from secondary sources such as peer reviewed literature, government reports, official records, grey literature, websites of various organisations, newsletters and brochures of organisations, and local newspapers. The gathered data and information were in numerical form as well as in text and pictorial form which were coded and categorised for the analysis. However, the hard data gathered from the project site were used for techno-economic feasibility analysis by applying the HOMER software. The focus of the analysis was to identify the possibility of introducing additional productive loads. All these provided some concrete insights on varied aspects of off-grid energy development in the country. The list of stakeholders interviewed is presented in the Appendix III. The key stakeholders interviewed consisted of financing institutions, NGOs, academicians, project developers, manufacturers, suppliers, government institutions, and donor agencies.

\section{Off-grid electrification in Sri Lanka: a historical account}

Development of off-grid energy systems in Sri Lanka as an electrification option can be traced back to the early 1900s, where mini and micro hydro systems were used to energise tea plantation and tea 
processing industries (AFREPREN, 2009). However, over time, these systems have started to become redundant with the expansion of grid-based electricity. Statistics indicate that about 500 such projects were abandoned around 1960s due to availability of grid-based electricity (Salih, 2012). However, there were efforts made by the government to again revive these small hydro projects. Small Hydro Programme of 1979 supported by Practical Action (then known as ITDG) was one such initiatives by the Government of Sri Lanka. In 1994, Government of Sri Lanka's took special effort to promote renewable energy based off-grid electrification to provide an effective alternative to households who are using car batteries to meet their basic electricity requirements. Government estimates suggests that about 0.3 million people were using such batteries for meeting their basic electricity requirements. All these patchy efforts were taken up in a more formalised, coherent and systematic manner through a donor supported programme known as 'Energy Service Delivery (ESD)' project, where the emphasis was given to exploit both grid and off-grid electrification options by using the renewable sources of energy.

Development of off-grid electrification in Sri Lanka can be divided into different phases. The phase one could be called the pre-ESD phase, where off-grid electrification in the country was primarily driven by the private sector largely for the purpose of energising tea estates and tea production and processing units. A host of patchy efforts were undertaken in this phase. The emphasis was limited in micro-hydro based energy systems. Various fiscal and financial incentives such as loans and subsidies as well as technical guidance were provided by the government of Sri Lanka. In addition, government also supported these initiatives by conducting various training and capacity building exercises from time to time.

Second phase of off-grid development in the country can logically be linked to the introduction of ESD project around 1997. The project was supported by the World Bank (WB) and Global Environment Facility (GEF) and implemented during 1997-2002. The project was designed on commercial principles through a market-based credit programme. Ten Participating Credits Institutions $^{2}$ (PCIs) - banks and non-bank financial institutions, were identified to extend credit for the wider deployment of projects. Apart from grid-based projects, two different off-grid technologies such as solar home systems (SHS) and village hydro schemes (VHS) were supported through this project. Electricity Consumer Societies (ECS) were formed as the legal entity for the operation and management of these projects. Project developers such as private investors, tea estate

\footnotetext{
2 These are institutions who took part in the credit disbursement to the project beneficiaries supported through ESD and RERED programmes. These credit institutions are DFCC Bank, National Development Bank (NDB), Hatton National Bank (HNB), Commercial Bank, Sampath Bank, and Sarvodaya Economic Enterprises Development Services (SEEDS)
} 
management companies, NGOs and village cooperatives acted as interlocutors in all matters such as guiding communities in the formation of ECSs, helping them on technical matters, giving them training and facilitating the funds mobilization. Funding was provided largely through market-based credit programmes. However, in some cases some complementary funding either in cash or in kind was also provided by the project beneficiaries. In addition to that, ESD programme also had provision of providing technical guidance to project developers to manage the projects effectively. During this first phase, about 35 village hydro schemes (VHS) ranging from 5 to $15 \mathrm{~kW}$ with a total cumulative capacity of $350 \mathrm{~kW}$ and 20953 SHSs totaling a capacity of about $984.6 \mathrm{~kW}$ (RERED, 2013; Sahil, 2012) were successfully implemented. In addition to it, the project also supported 31 MW mini-hydro grid connected projects. All these contributed to leapfrogging of electricity rates in the country from $41 \%$ in 1997 to $60 \%$ in 2002 (Amarawickrama and Hunt, 2004).

The third phase could be called as post-ESD phase, implemented through the programme 'Renewable Energy for Rural Economic Development (RERED)', during 2003 to 2007, furthe extended till 2011. Government of Sri Lanka had mobilized funds from IDA of World Bank and GEF through this new programme RERED for expansion of electrification in the country. This programme led to electrification of about 4137 households through village hydro systems (VHS) and 94,242 households through solar home systems (SHS) with a total capacity addition of about 4186.5 kW and 80.16 MW of grid connected mini-hydro projects (RERED, 2013; Sahil, 2012). The programme got extended further as RERED-AF. An additional capacity of $580 \mathrm{~kW}$ was created through village hydro systems (VHS) serving about 1797 households, 16,333 SHS totaling a capacity of $618 \mathrm{~kW}$ and $60.34 \mathrm{MW}$ of grid connected mini-hydro projects were also deployed under this programme (RERED, 2013; Sahil, 2012). Total off-grid renewable energy capacity created in this phase is about $8 \mathrm{MW}$ and 1,30,000 households have been electrified through various off-grid routes (PUCSL, 2013).

Off-grid energy revolution in the country reveals certain interesting patterns. For instance, it can be observed from the designing of the capacity of these projects that capacity of small-hydro projects has increased over years on an experimental basis. Starting from the pre-ESD phase where the average plant sizes used to be $2 \mathrm{kWe}$, the recent projects are of larger sizes with capacity ranging between 5 to $7 \mathrm{kWe}$ and even more (Wickramasinghe, 2013). Second, starting from pre-ESD era, off-grid energy developments in the country have been largely supported by a host of donor agencies such as International Development Agency (IDA) of the World Bank (WB), Global Environment Facility (GEF), and Asian Development Bank (ADB), South Asia Cooperative 
Environment Programme (SACEP), South Asia Renewable Energy Programme (SAREP), Intermediate Technology Development Group (ITDG - now Practical Action), Energy Forum, RESCO Asia, Shell Renewables, and the Institutional Design of the Cooperative Implementation Mechanism of the Kyoto Protocol. The next section offers a detailed explanation of policy and institutional setting for such projects.

\section{Policy and institutional framework governing the off-grid energy sector}

Energy governance does play a significant role in shaping up the energy development contours of any country. The present section dwells on key political, legal and institutional considerations of the country that has shaped the off-grid energy development in Sri Lanka. In the political sphere, while federal government plays a crucial role in announcing certain policies and regulations, provincial governments have supported off-grid electricity initiatives by providing financial assistance, often, from their own budget, and have contributed in strengthening the local capacities of electric community societies. Institutionally, the responsibility of electrifying households lies with the federal government through a host of institutions and entities such as the Ministry of Power and Energy, Sri Lanka Sustainable Energy Authority (SLSEA) and Energy and Public Utilities Commission (PUCSL), Sri Lanka. While the Ministry of Power and Energy is responsible for the overall management of the power sector, SLSEA is entrusted with the development of renewable energy in the country including off-grid renewable energy projects. On the other hand, PUCSL is the authorised body to deal with the regulatory aspects with specific reference to the interconnection issues of off-grid energy projects. Mapping of these actors and entities is presented in the figure below (Figure 1). 


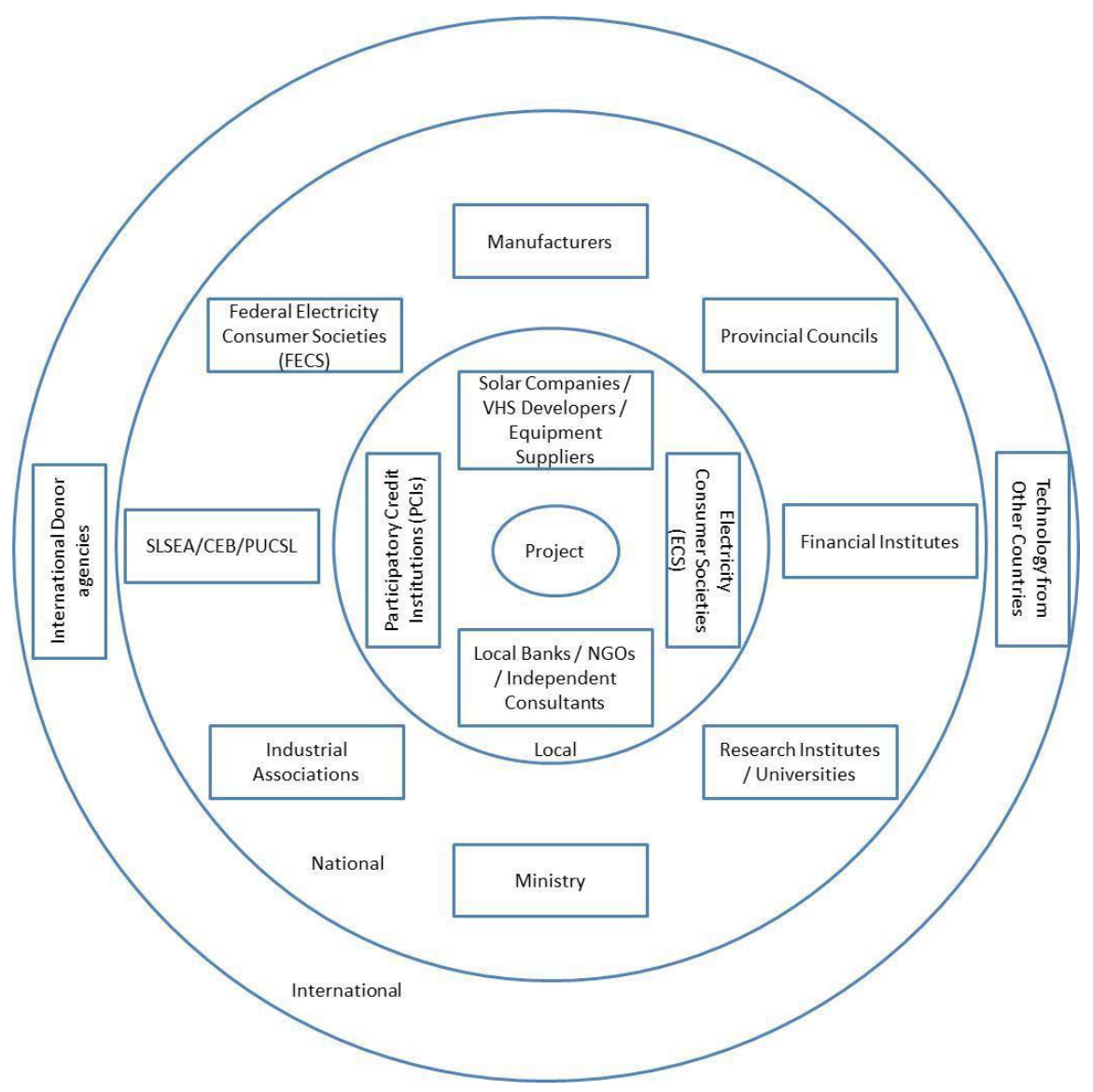

Figure 1: Involvement of various stakeholders for the development of off-grid sector in Sri Lanka.

Source: Authors construct

Tracing the history of off-grid energy policy evolution in the country unfolds that the first National Energy Policy of Sri Lanka was drafted in 1997 by the National Energy Policy Committee (NEPC) formed under the Ministry of Power and Energy, however, it never got formalised (Sugathapala, 2002). Nevertheless, it had laid down the future roadmap of the sector in the country. The policy first time in the history of energy policy making in the country had underscored the importance of energy for the economic growth of the country. The draft policy document had assigned importance to access to energy for all and developing renewable energy resources of the country. It highlighted the role of off-grid projects in areas deprived of grid-based electrification systems.

Further development in the policy space occurred with the enactment of National Energy Policy and Strategies (NEPS) in 2005 by the Ministry of Power and Energy of Sri Lanka, which was the first formalised energy policy statement of the Government of Sri Lanka. The policy had laid thrust on implementation strategies, specific energy targets, and strategies for achieving millennium development goals (MDGs). The policy had given priority to improving the household electricity, 
particularly in rural areas, providing basic energy needs to all, enhancing energy security, and bettering quality of energy services. The policy in particular had assigned the responsibility on Provincial Councils to develop off-grid electrification in the country as an alternative mode of electrification. The policy was aiming at electrifying $98 \%$ of the households in Sri Lanka by 2016 through both grid-based as well as off-grid systems (Ferdinando and Gunawardana, 2008). The next major move was the setting up of a new institution Sri Lanka Sustainable Energy Authority (SLSEA) in 2007, through SLSEA Act, which was primarily aiming at boosting the country's renewable energy capacity. The SLESA Act has clear provisions related to renewable based off-grid electricity generation, supply and distribution, and demarcation of geographical areas to be electrified through off-grid systems. It had laid down a clear roadmap for off-grid energy projects by stating that national grid can be extended to cover $97 \%$ of the population, and the remaining $3 \%$ is covered by off-grid systems. Accordingly, Ceylon Electricity Board $\left(\mathrm{CEB}^{3}\right)$ also had come up with the list of villages for off-grid projects.

Sri Lanka Electricity Act 2009 was the latest policy statement by the Government of Sri Lanka in the field of energy. One of is the key provisions of the Act deals with the issue of interconnection of offgrid projects with the grid. The Act has clear provisions related to technical, tariff and ownership matters associated with grid-interconnection mechanism of off-grid systems. These interconnection provisions are only meant for community-based village micro-hydro projects.

It appears from various policies declared from time to time that some sort of incremental policy learning has happened over the past few decades in designing of energy policies in Sri Lanka. It seems that the lessons learnt from a past policies have fed into the designing of new policy statements. This is evident as starting from National Energy Policy of Sri Lanka, 1997 up to Sri Lanka Electricity Act 2009, one can find how the scope of different policies pronounced from time to time has gradually widened and how policies have designed to tackle the contemporary challenges of the sector prevailing during the declaration of such policies. For instance, latest policy i.e. Sri Lanka Electricity Act 2009 has a clear emphasis on grid-interconnection issues - one of the burning issues worldwide related to off-grid energy development. The next section offers an analytical explanation of the key features of off-grid energy sector in Sri Lanka.

\footnotetext{
${ }^{3}$ The Ceylon Electricity Board (CEB), is the largest government owned electricity company established in 1969 in Sri Lanka. CEB controls the functions of generation, transmission and distribution of electricity in SriLanka.
} 


\section{Key operational features of off-grid energy systems in Sri Lanka}

It is interesting to explore key aspects of off-grid electrification in Sri Lanka. Here we discuss certain key characteristics of off-grid projects drawing from secondary sources, interviews and field experiences gained during our field visits.

\subsection{Largely community centric interventions}

Even though the implementation modalities of the off-grid electrification programmes such as ESD, RERED and RERED-AF differ in many ways, there exist commonalities across such programmes. Micro-grid projects promoted through these programmes are largely community-based interventions and implemented by the community-based village level entities known as 'Electricity Consumer Societies (ECS)' and supported and facilitated by project developers such as tea estate management companies, private investors, NGOs and village cooperatives etc. Communities as beneficiaries often contribute in cash and in kind to the project development and management. The ECS is responsible for all sorts of local administrative responsibilities such as managing non-payment of monthly fees, resolving disputes arising among members and often small technical issues related to the project operation and management, and owns the project. However, the project developers, as key stakeholder of such projects, do play a crucial role. Project developers are engaged with a variety of activities such as identification of the site, carrying out the feasibility and demand assessments, getting the necessary clearances and statutory approvals from the respective authorities and mobilising the necessary finances through the micro-credit institutions (PCIs), conducting the social mobilising by motivating communities and forming the ECS etc. It emerged from the discussion with various stakeholders that communities encounter multiple problems in terms of getting necessary clearances from various authorities, arranging necessary finances from credit institutions during the implementation of the project. The success often depends upon efficiency of project developers and formation of an active ECS. In many cases, lack of social mobilisation and organisational skills have led to social conflicts and delayed the project implementations.

\subsection{Quite a complex financial architecture}

In case of micro-hydro projects, the finance for the project is mobilised through four different sources i.e. contribution from the community, co-financing or grants from the provincial councils, loans from the banks or financing institutions, and capital subsidy in the form of co-financing grants through Government programmes. In general, while $30 \%$ of the project costs are borne by the beneficiaries, $50 \%$ of the project costs come through loans and grants and rest $20 \%$ are in the form 
of co-financing and occasional grants from the provincial councils. Ten PCIs have been identified to disburse the credits to the project beneficiaries. While administrative unit created within the DFCC Bank controlled the projects centrally in disbursement of credits, PCIs administer the projects in a decentralised mode. The loan approval process is linked to the project viability and ability to pay back the loans. For this, a project feasibility report is to be submitted which should be endorsed by the project engineer and a socio-economic survey carried by the developer. The project feasibility study is carried out by developers through a trained specialist in this field and audited by an engineer appointed by loan or grant disbursing agencies. The co-financing capital grants are provided on the basis of capacity of the project size - at the rate of $400 \mathrm{USD} / \mathrm{kW}$ with a maximum of $20000 \mathrm{USD}$.

On subsidy disbursement front, it was evident that there has been a policy learning gradually built into the policy making process and has led to redesigning of subsidies from time to time. For example, when the ESD programme was further extended and became RERED, new ways of disbursing subsidies were also introduced. Subsidies for off-grid renewable energy projects are channelized through provincial councils from their decentralised budget for energy. However, it is found that disbursement of subsidies is often subjected to political motives and vested political interests, selectivity, corrupt political practices, and lack of knowledge and interest of provincial councils about the renewable energy.

\subsection{Relatively stringent approval process}

Starting from the conceptualization stage till up to the implementation of off-grid projects, a series of approvals is required from different authorities and agencies in order to run the project smoothly. One of the initial approvals is related to the certification from Ceylon Electricity Board (CEB) about the lack of grid access in the prospective area and hence the need for off-grid solutions. CEB also ensures that the proposed village hydro project has received water use rights and land use permits from the appropriate authority. In case of water right permits, it is basically the right to divert and use water for specific purposes and this permit is given against a fee. Similarly, land use rights are given by the Divisional Secretaries of the respective provinces. In addition, other requirements like environmental clearances from Central Environment Authority (CEA), clearances by controllers of reservations, construction permit by local authorities, loan approvals by the financial institutes, grant approvals by the provincial councils, and installed verifications by chartered engineers are necessary approvals for initiating the project. Environmental clearances usually require initial examination of the environment and a fee is paid for getting that. 


\subsection{Strong emphasis on capacity buildings}

Capacity building is undertaken at different layers of the project execution and management and for a host of stakeholders. There exist industrial associations for each renewable energy technologies like solar, biogas, and village micro hydro developers, who at a macro-scale continue to build capacities. An umbrella organization called Federation of Electricity Consumer Society (FECS), created in 2002 to represent the concerns of ECS also conducts a variety of training, capacity building and awareness programmes. FECS offers training in leadership, management and accounting processes of project management. By 2011, FECS has conducted 18 capacity building workshops, and has trained about 600 village leaders. Apart from the above, the donor agencies, financing institutions, banks, and programme units have set up dedicated training and technical assistance divisions to conduct necessary training activities on technology standards, and operation and maintenance of the system. Several other agencies engaged in the off-grid energy space in Sri Lanka such as Energy Forum, RESCO Asia Ltd., Shell Renewables, Ceylon Electrification Board (CEB), and the Intermediated Technology Development Group (ITDG)- Now Practical Action), also conduct awareness and training programmes from time to time for rural communities, project developers, project consultants, NGOs, and policymakers. Importantly, a host of academic institutions like University of Moratuwa, Open University, British Council and University of Sheffield jointly organise a programme called the 'Higher Education Link (HEL)' to give practical demonstration training on operation and assembling of SHS. The recent focus on training is laid on building the capacities of ECSs, keeping in consideration of future challenges of grid interconnection of off-grid projects. Though, formally there exist a very strong institutional setting to build capacities of various stakeholders engaged in off-grid energy development in the country, it was revealed from the interviews that in certain cases operators are ill-trained to operate the projects, Often, these works are outsourced to external technicians having cost implications for the beneficiaries. In addition, since these projects are in remote areas, execution of such training programmes is not an easy task often.

\subsection{Inadequate quality control mechanisms}

Technical norms and standards are important for renewable energy based off-grid systems. The Administrative Unit of DFCC Bank has a technical standard consultant for providing necessary guidance on technical compliance to the customers on solar home systems (SHS) and village hydro systems (VHS). There exist standard norms and specifications for SHS and VHS to ensure the quality, and safety of the systems, introduced by the RERED. These norms and standards developed 
by the RERED, are periodically revised according to the market developments, advancement in technologies, and donor/consultants' suggestions. National Engineering Research and Development (NERD) Center has been working on SHS quality testing. In addition, Sri Lanka Standards Institute (SLS) through the support from Energy Forum has developed a code of practice for micro-hydro projects. The code of practice requires certain specifications such as certifying the equipment, publishing technical manuals, and service agreements (PUCSL, 2013). However, it was found that often projects were hampered due to sub-standard electro-magnetic equipment. A survey by PUCSL reveals that there is lack of documentation relating to the specification of equipment (PUCSL, 2013). Often procurement of mechanical and electrical equipment is carried out without having proper contract agreements. As a result, there were regular breakdowns of such equipment.

\subsection{Wavering grid interconnection issues}

Of late, one of most challenging problems encountered by the off-grid projects in Sri Lanka is related to the grid interconnection of off-grid projects. The list of villages identified by PUCSL to be provided with off-grid solutions indicates that grid will reach all the existing off-grid villages which enjoy renewable energy based off-grid solutions. This poses a challenge of grid interconnection of existing off-grid projects. There have been recent pilot efforts to connect off-grid projects with the national grid in order to explore the technical, legal and social barriers of interconnecting off-grid projects with the national grid. Interconnecting regulations differ depending on the ownership structure of such projects.

In case of privately-owned projects, the procedure is rather simple, and a standard practice has been set. A project developer has to first get the 'Energy Permit' from SLSEA and 'Generation License' from PUCSL, before it signs the power purchase agreement (PPA) with the CEB. However, in case of community-based projects, the procedure is rather complex and involves resolving a wide range of technical, social, administrative and financial issues. On technical front, designing of appropriate control panel is the major challenge. In addition, converting the existing distribution systems to meet the CEB standards is also technically and financially a cumbersome affair. On social front, converting the voluntarily operating ECSs into commercial legal entities is a cumbersome affair. Administratively, a whole set of approvals are required for grid interconnection of these off-grid projects. Apart from approvals such as energy permits from SLSEA, generation license from the PUCSL, power purchase agreements from CEB, other approvals such as approvals from provincial authorities are also required for operationalizing the process of grid interconnection (Subasinghe, 2017). On finance matters, community-based projects also encounter difficulties in mobilising the 
necessary finances for converting these community run projects into some sort of business ventures. This is because communities lack required collateral for mobilising the necessary finance from the banking institutions. Hence, small size of these projects makes them difficult to become commercially viable (ESMAP, 2018). The pilot experiences gained through two different projects suggest that the interconnection fees imposed by CEB and SLSEA are exorbitantly high and needs to be reduced in order to make interconnection effective.

However, these interconnection issues are very much entrenched with the prevailing feed-in-tariff mechanism of the country. Though in Sri Lanka feed-in-tariff was introduced to promote renewable energy technologies for power plants less than $10 \mathrm{MW}$, however, many of these small-scale projects do not get benefitted through the existing FiT mechanism. FiT was initially introduced on the principle of 'avoided cost' calculated as cost the utility would have incurred if the same amount of energy would have procured by using conventional fuel sources. This was further revised in 2007 with technology specific cost-based tariff calculation. However, the existing FiT policy does not appear to be considering small projects into consideration (ADB and UNDP, 2017). It is posited that smaller renewable energy projects should be allowed to charge higher tariffs compared to larger renewable energy projects, which has not been provisioned in the existing FiT scheme. This would have helped them to resolve the interconnection issues.

While the above sections offer critical analysis of off-grid energy project development and their salience features, attempt is made in the next section to carry out a detailed techno-economic assessment of a micro-hydro project to understand the ground level experiences of implementation of such projects.

\section{Case study analysis of a village micro-hydro project}

The studied project is located in the Kavittikanda, a village in the Ayagama divisional secretariat area of Ratnapura district within the province of Sabaragamuwa of Sri Lanka. The project is known as Maha Dola Village Micro Hydro Power Project, which is on the river Maha Dola, a tributary of Paragala Ganga and Kalu Ganga. The project site is about $80 \mathrm{~km}$ away from Colombo, the capital city of Sri Lanka. The project was promoted and developed under the RERED village electrification programme in Sri Lanka spearheaded by the World Bank. The complete financial details of Maha Dola village micro-hydro project are shown in Appendix I. The project was commissioned in 2010. The detailed profile of the project is presented in the table below (Table 1). 
The project village i.e. Kavittikanda village is small in size, consisting of only 37 Households (HHs), with a total population of about 130 . Income distribution pattern of the village reveals that there are 7 low income $\mathrm{HHs}, 16$ middle income $\mathrm{HHs}$ and 14 high income $\mathrm{HHs}$ in the village. The village is located in a hilly area and the households are scattered within a radius of $1.5 \mathrm{~km}$ of the project location. As per guidelines of RERED programme, villagers have formed Maha Dola Electricity Consumers Society (Mahadola- ECS) to operate and manage the project.

\begin{tabular}{ll}
\hline Name of the project & $\begin{array}{l}\text { Maha Dola Village Micro Hydro Power Project } \\
\text { Location }\end{array}$ \\
& $\begin{array}{l}\text { Kavittikanda, village in the Ayagama divisional secretariat } \\
\text { area of Ratnapura district (in the province of } \\
\text { Sabaragamuwa of Sri Lanka) } \\
\text { Size of the plant }\end{array}$ \\
Total number of HHs in the village & $37.5 \mathrm{~kW}$ \\
Sponsored by & RERED Programme of World Bank \\
Year of Installation & 2010
\end{tabular}

Table 1: Project profile of Mahadola village hydro projectx

Socio-economic profile of the village is not very encouraging. Occupation statistics show that villagers are mainly engaged in primary sector activities such as cultivation of tea, rubber, and a small amount of cinnamon plantation etc. The village is largely devoid of basic minimum level of infrastructure facilities like schools, hospitals, and community centres. Grid based electrification was not a feasible option for the village, given that it is located in a geographically difficult region of hilly area. This is the reason why this village was chosen to be provided off-grid solutions through RERED programme of the World Bank. The village level basic survey conducted during the feasibility study of the project by the project developer reveals that on an average each household was spending about Sri Lankan Rupees 2150 per month (18 USD) on energy (largely on kerosene) before the project was implemented. From the discussion with the local residents, it emerged that the project has been benefitting villagers in multiple ways. Not only villagers use lighting facilities but also several households in the village are using various other electrical appliances like radio, TV, Iron-box, VCD player, grinder. Fig 2 shows a household using TV. In this section, a technoeconomic assessment of the Maha Dola Micro-hydro Power Project is carried out to understand the basic economics of the project operation by estimating key economic indicators such as unit cost of 
electricity supply, cash flows, and pay back periods. In addition, the analysis also develops possible future scenarios for the optimal use of the excess energy being generated.

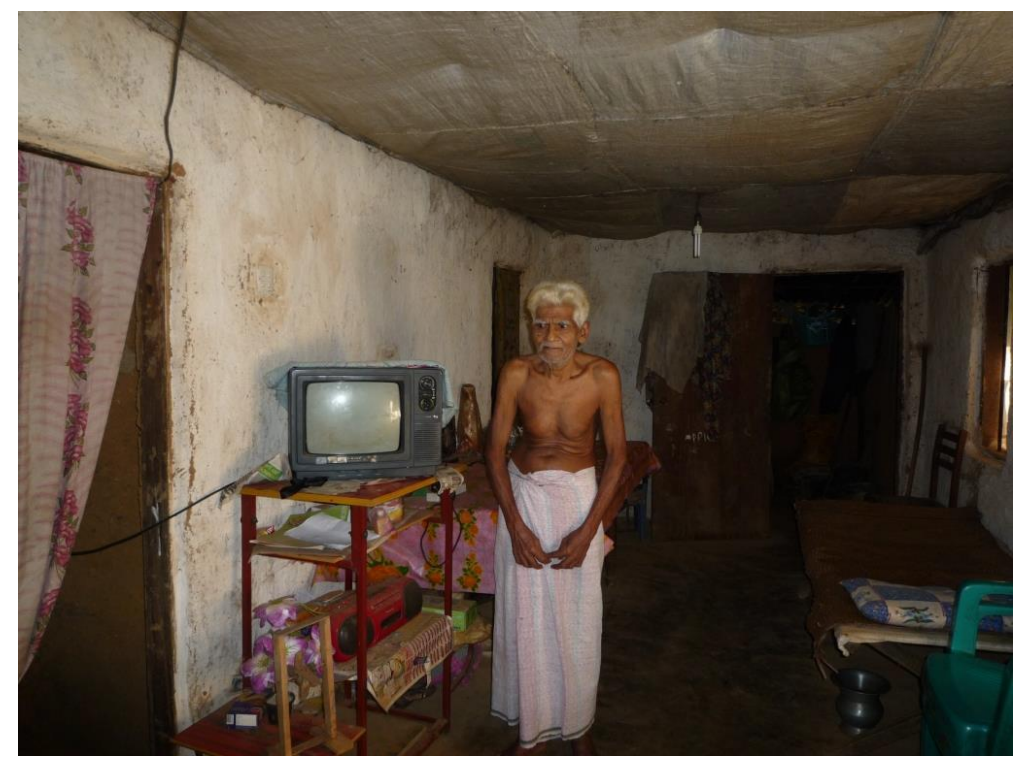

Figure 2: Legend showing a household using a television set

Current pattern of electricity use statistics reveals that electricity is primarily used by the villagers for lighting and entertainment purposes, with very limited use of electrical appliances such as iron boxes, rice grinders, and VCD players. (Refer current load scenario in Table 2 for the details). Electricity supply is restricted to only a few hours in day with total AC primary load of the community of $30,024 \mathrm{kWh} /$ Year. However, given the project size, it generates about 55,879 $\mathrm{kWh} /$ Year, thereby an excess energy generation of about $25,855 \mathrm{kWh} /$ year, almost $46.7 \%$ of total generation, which is being wasted by channelizing this energy to heat 14 x $750 \mathrm{~W}$ electric rods, in order to avoid any technical malfunctioning of the system. Daily average consumption of the village is estimated to be around $81 \mathrm{kWh}$ /day with the load factor of 0.294 . The peak load of the system is calculated to be around $6.42 \mathrm{~kW}$. The down time of the plant is estimated to be very low and the plant has not required any major maintenance so far. The hourly load profile of the current scenario is shown in Fig 3. The current capacity utilization factor (CUF) of the plant comes out to be $45 \%$. The levelized cost of electricity (LCOE) is estimated to be $0.072 \$ / \mathrm{kWh}$. The detailed list of parameters considered for the estimation of the LCOE is presented in the Table 3. We also attempted to find out the annualized cash flow of the plant as shown in Fig 4. A flat rate of $1.25 \mathrm{USD}^{4}$ per

\footnotetext{
${ }^{4}$ The conversion rate between USD and SLR is, 1 USD $=120$ Sri Lankan Rupee (SLR)
} 
month is being collected from each $\mathrm{HH}$, which is sufficient to recover plant operating and maintenance costs. From this $1.25 \mathrm{USD}$, they are spending 0.417 USD for the O \& M and the 0.833 USD is being deposited in the bank for the loan repayment.

\begin{tabular}{|c|c|c|c|c|c|}
\hline \multicolumn{2}{|c|}{ Low Income HHs } & \multicolumn{2}{|c|}{ Middle Income HHs } & \multicolumn{2}{|c|}{ High Income HHs } \\
\hline $\begin{array}{l}\text { Type-1 } \\
\text { (5 HHs) }\end{array}$ & $\begin{array}{l}\text { Type-2 } \\
\text { (2 HHs) }\end{array}$ & $\begin{array}{l}\text { Type-3 } \\
\text { (2 HHs) }\end{array}$ & $\begin{array}{l}\text { Type-4 } \\
\text { (14 HHs) }\end{array}$ & $\begin{array}{l}\text { Type-5 } \\
\text { (10 HHs) }\end{array}$ & $\begin{array}{l}\text { Type-6 } \\
\text { (4 HHs) }\end{array}$ \\
\hline $\begin{array}{l}3 \times 12 \mathrm{~W} \\
\text { lighting } \\
\text { load for } \\
6 \mathrm{Hrs}\end{array}$ & $\begin{array}{l}\text { Hrs and } \\
1 \times 10 \text { W } \\
\text { radio load } \\
\text { for } 5 \mathrm{Hrs}\end{array}$ & $\begin{array}{l}5 \times 12 \text { W } \\
\text { lighting load } \\
\text { for } 6 \text { Hrs, } \\
1 \times 10 \mathrm{~W} \text { radio } \\
\text { load for } 5 \\
\text { Hrs, and } \\
\text { 1x1000 W } \\
\text { iron box load } \\
\text { for } 2 \text { Hrs }\end{array}$ & $\begin{array}{l}\text { lighting load } \\
\text { for } 6 \text { Hrs, } \\
1 \times 10 \mathrm{~W} \text { radio } \\
\text { load for } 5 \\
\text { Hrs, and } \\
\begin{array}{ll}\text { 1x150 } \mathrm{W} & \mathrm{TV} \\
\text { load for } & 4 \\
\text { Hrs }\end{array}\end{array}$ & $\begin{array}{l}6 \times 12 \mathrm{~W} \text { lighting } \\
\text { load for } 6 \mathrm{Hrs,} \\
1 \times 10 \mathrm{~W} \text { radio load } \\
\text { for } 5 \mathrm{Hrs}, 1 \times 150 \mathrm{~W} \\
\text { TV load for } 4 \mathrm{Hrs,} \\
\text { and } 1 \times 1000 \mathrm{~W} \\
\text { electrical } \\
\text { appliances load for } \\
3 \mathrm{Hrs}\end{array}$ & $\begin{array}{l}\text { for } 6 \mathrm{Hrs}, 1 \times 10 \mathrm{~W} \\
\text { radio load for } 5 \mathrm{Hrs} \text {, } \\
1 \times 150 \mathrm{~W} \text { TV load for } \\
4 \mathrm{Hrs}, 1 \times 1000 \mathrm{~W} \\
\text { electrical appliances } \\
\text { load for } 3 \mathrm{Hrs} \text { and } \\
1 \times 5000 \mathrm{~W} \text { rice } \\
\text { grinder for } 2 \mathrm{Hrs}\end{array}$ \\
\hline
\end{tabular}

Table 2: Current load scenario of the plant

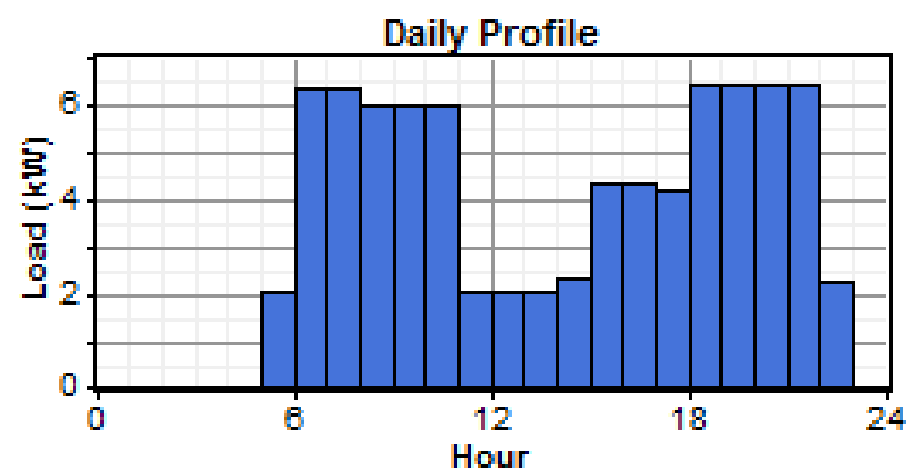

Figure 3: Hourly load profile of the village in a day 


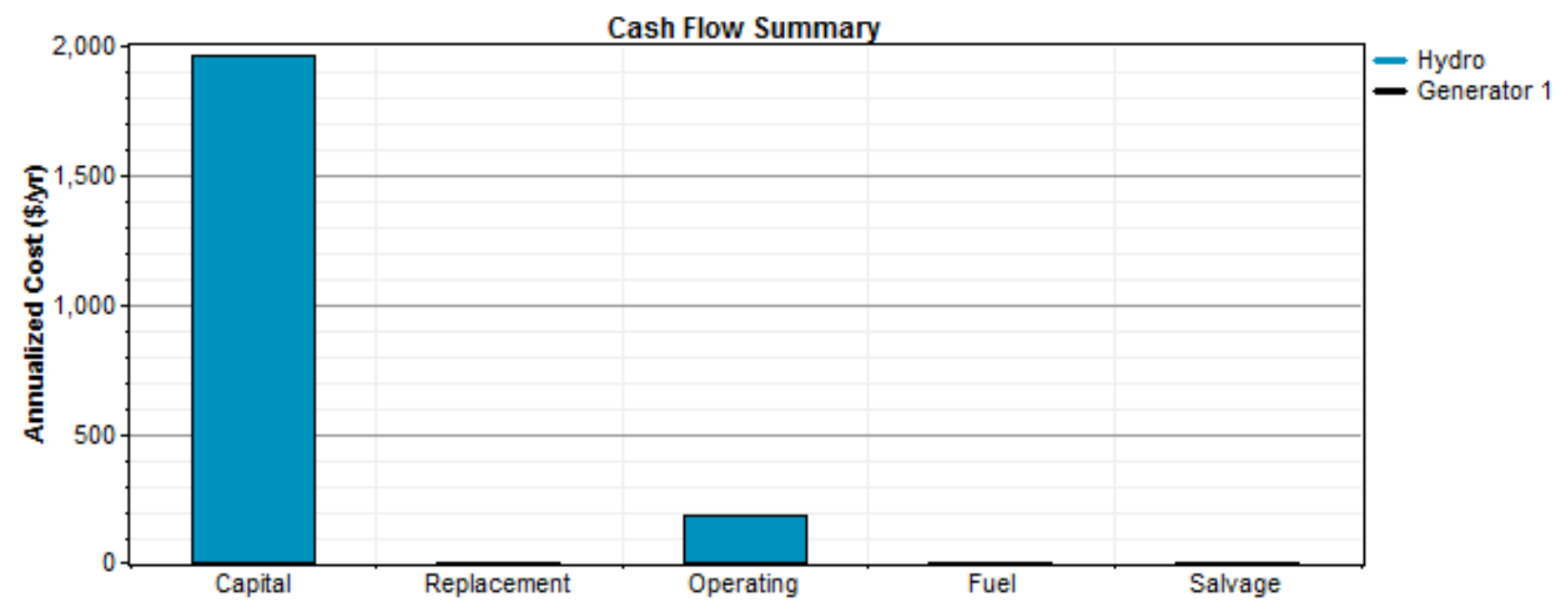

Figure 4: Annualized cash flow summary of the plant for the base case.

The cost mentioned in the cash flow is of annualized cost of the plant, and it is mentioned that capital cost of the system includes the balance of the system, operating cost is the cost of manpower and fuel cost - shown here is the diesel cost of backup generator, but the fuel cost is very negligible amount. We also compared the micro-hydro with the solar power for the same current load profile of 81 $\mathrm{kWh}$ /day (Please refer Table 3). The levelized unit cost of electricity for the solar based system is $0.289 \$ / \mathrm{kWh}$. The design of solar PV system was made on the assumptions of $4 \mathrm{hrs}$ peak sunshine (SLSEA, 2013). A $26 \mathrm{kWp}$ solar PV plant could electrify that village for the present load pattern. The cost of the system ${ }^{5}$ is $\$ 68320$, which includes the battery cost, inverter cost, module cost, and civil and mounting structure costs. The analysis clearly indicates that the solar PV system for the present load profile in the village is not feasible.

\begin{tabular}{|c|c|c|c|}
\hline Parameter & Unit & Micro hydro & Solar PV \\
\hline Rated power capacity & $\mathrm{kW}$ & 7.5 & 26 \\
\hline Annual power generation & $\mathrm{kWh}$ & 55879 & 38147 \\
\hline Life span of the plant & Years & 25 & 20 \\
\hline Capital cost of the plant & USD & 15375.00 & 68320.00 \\
\hline Annual $\mathrm{O} \& \mathrm{M} \operatorname{cost}^{6}$ & USD & 185.00 & 2243.00 \\
\hline Annual $O \&$ M escalation rate & $\%$ & 5.00 & 5.00 \\
\hline Discount rate & $\%$ & 12.00 & 12.00 \\
\hline Loan amount & USD & 7041.67 & NA \\
\hline Grant amount & USD & 3750.00 & NA \\
\hline Loan interest rate & $\%$ & $\mathrm{AWDR}+3.50 \%$ & $12.00 \%$ \\
\hline
\end{tabular}

Table 3: Parameters for LCOE for $7.5 \mathrm{~kW}$ village micro hydro plant

\footnotetext{
${ }^{5}$ Battery, inverter and PV module costs are taken from the local companies in Sri Lanka.

${ }^{6}$ Annual $\mathrm{O} \& \mathrm{M}$ costs includes of man power costs, maintenance of the system, $\mathrm{T} \& \mathrm{D}$, etc.
} 
Source: Kohle, 2013; Nouni et al, 2006; Palit et al, 2012

It is evident from the above that under the current usage pattern the plant generates substantial quantum of excess energy. Therefore, it is logical to think of optimising the available excess energy by introducing additional productive loads. We envisaged three different scenarios with increasing loads by introducing additional productive application of energy. These scenarios are visualised, keeping in mind the socio-economic realities of the village and feasibility of creating possible productive loads. The details of three different scenarios are presented in the Tables below (Table 4, Table 5, and Fig 5). 


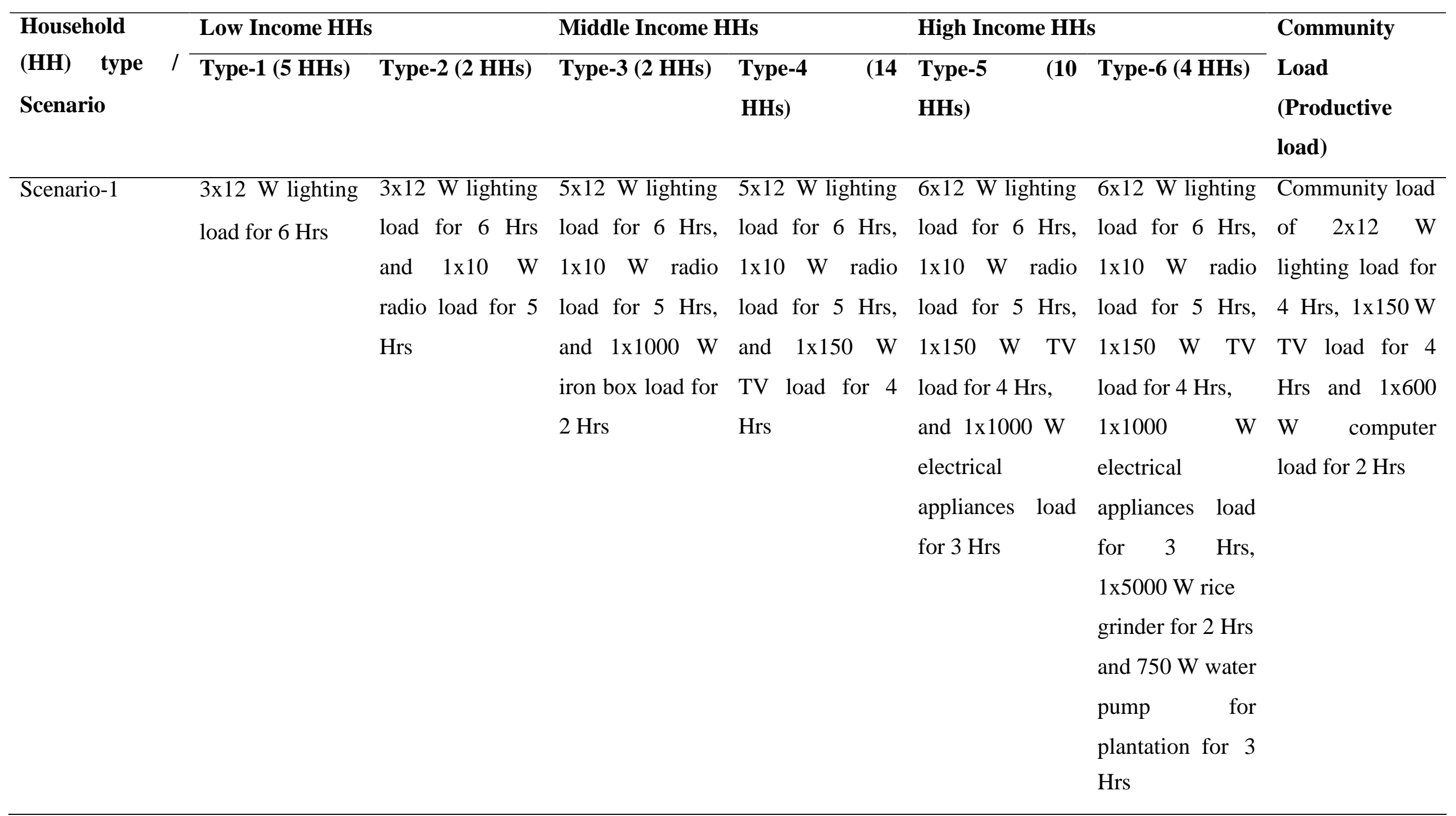




\begin{tabular}{|c|c|c|c|c|c|c|c|}
\hline Scenario-2 & $\begin{array}{l}3 \times 12 \mathrm{~W} \text { lighting } \\
\text { load for } 6 \mathrm{Hrs}\end{array}$ & $\begin{array}{l}3 \times 12 \mathrm{~W} \text { lighting } \\
\text { load for } 6 \mathrm{Hrs} \\
\text { and } 1 \times 10 \mathrm{~W} \\
\text { radio load for } 5 \\
\text { Hrs }\end{array}$ & $\begin{array}{l}5 \times 12 \mathrm{~W} \text { lighting } \\
\text { load for } 6 \mathrm{Hrs} \text {, } \\
1 \times 10 \mathrm{~W} \text { radio } \\
\text { load for } 5 \mathrm{Hrs,} \\
\text { and } 1 \times 1000 \mathrm{~W} \\
\text { iron box load for } \\
2 \mathrm{Hrs}\end{array}$ & $\begin{array}{l}5 \times 12 \mathrm{~W} \text { lighting } \\
\text { load for } 6 \mathrm{Hrs} \text {, } \\
1 \times 10 \mathrm{~W} \text { radio } \\
\text { load for } 5 \mathrm{Hrs} \text {, } \\
\text { and } 1 \times 150 \mathrm{~W} \\
\mathrm{TV} \text { load for } 4 \\
\text { Hrs }\end{array}$ & $\begin{array}{l}6 \times 12 \mathrm{~W} \text { lighting } \\
\text { load for } 6 \mathrm{Hrs} \text {, } \\
1 \times 10 \mathrm{~W} \text { radio } \\
\text { load for } 5 \mathrm{Hrs,} \\
1 \times 150 \mathrm{~W} \mathrm{TV} \\
\text { load for } 4 \mathrm{Hrs} \text {, } \\
\text { and } 1 \times 1000 \mathrm{~W} \\
\text { electrical } \\
\text { appliances load } \\
\text { for } 3 \mathrm{Hrs}\end{array}$ & 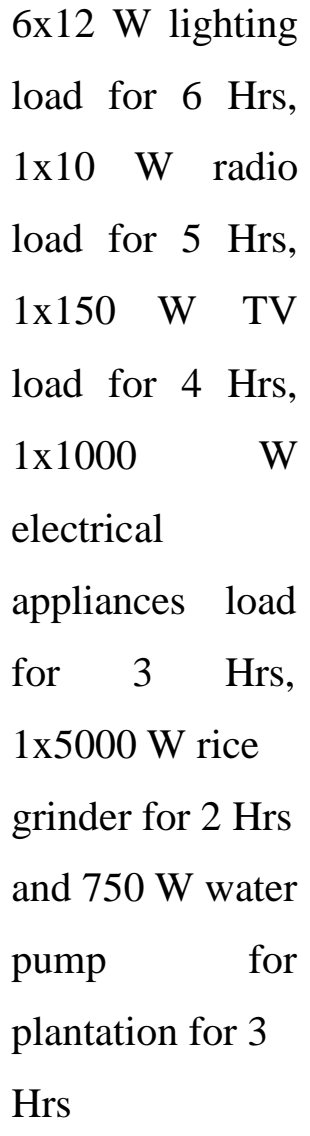 & $\begin{array}{l}\text { Community load } \\
\text { of } 2 \times 12 \text { W } \\
\text { lighting load for } \\
4 \mathrm{Hrs}, 1 \times 150 \mathrm{~W} \\
\mathrm{TV} \text { load for } 4 \\
\mathrm{Hrs} \text { and } 1 \times 600 \\
\mathrm{~W} \text { computer } \\
\text { load for } 2 \text { Hrs } \\
\text { and } 1 \text { tea garden } \\
\text { machinery } \\
3500 \mathrm{~W} \text { for } 6 \\
\text { Hrs }\end{array}$ \\
\hline Scenario-3 & $\begin{array}{l}3 \times 12 \mathrm{~W} \text { lighting } \\
\text { load for } 6 \mathrm{Hrs}\end{array}$ & $\begin{array}{l}3 \times 12 \mathrm{~W} \text { lighting } \\
\text { load for } 6 \mathrm{Hrs} \\
\text { and } 1 \times 10 \mathrm{~W} \\
\text { radio load for } 5 \\
\text { Hrs }\end{array}$ & $\begin{array}{l}5 \times 12 \mathrm{~W} \text { lighting } \\
\text { load for } 6 \mathrm{Hrs} \text {, } \\
1 \times 10 \mathrm{~W} \text { radio } \\
\text { load for } 5 \mathrm{Hrs} \text {, } \\
\text { and } 1 \times 1000 \mathrm{~W}\end{array}$ & $\begin{array}{l}5 \times 12 \mathrm{~W} \text { lighting } \\
\text { load for } 6 \mathrm{Hrs} \text {, } \\
1 \times 10 \mathrm{~W} \text { radio } \\
\text { load for } 5 \mathrm{Hrs} \text {, } \\
\text { and } 1 \times 150 \mathrm{~W}\end{array}$ & 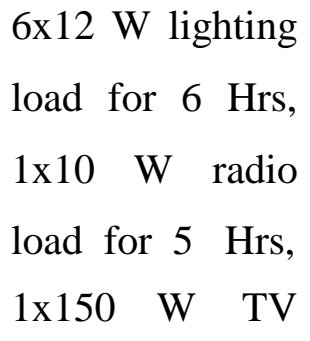 & $\begin{array}{l}6 \times 12 \mathrm{~W} \text { lighting } \\
\text { load for } 6 \mathrm{Hrs,} \\
1 \times 10 \mathrm{~W} \text { radio } \\
\text { load for } 5 \mathrm{Hrs,} \\
1 \times 150 \mathrm{~W} \quad \mathrm{TV}\end{array}$ & $\begin{array}{l}\text { Community load } \\
\text { of } 2 \times 12 \text { W } \\
\text { lighting load for } \\
4 \mathrm{Hrs}, 1 \times 150 \mathrm{~W} \\
\text { TV load for } 4\end{array}$ \\
\hline
\end{tabular}


TV load for 4

Hrs load for 4 Hrs,

and $1 \times 1000 \mathrm{~W}$

electrical

appliances load

for $3 \mathrm{Hrs}$ load for 4 Hrs,

$1 \times 1000$

electrical

W W pliances load and 2 tea garden for 3 Hrs, machineries of $1 \times 5000 \mathrm{~W}$ rice $3500 \mathrm{~W}$ for 6 grinder for $2 \mathrm{Hrs} \mathrm{Hrs}$ and $750 \mathrm{~W}$ water

pump for

plantation for 3

Hrs

Table 4: Daily usage projected under different scenarios 


\begin{tabular}{lll}
\hline Scenarios & Average kWh per day & Load factor \\
\hline Base case & 81.0 & 0.294 \\
Scenario-1 & 92.0 & 0.325 \\
Scenario-2 & 113.0 & 0.399 \\
Scenario-3 & 133.0 & 0.472
\end{tabular}

Table 5: Daily load profiles estimated under different scenarios
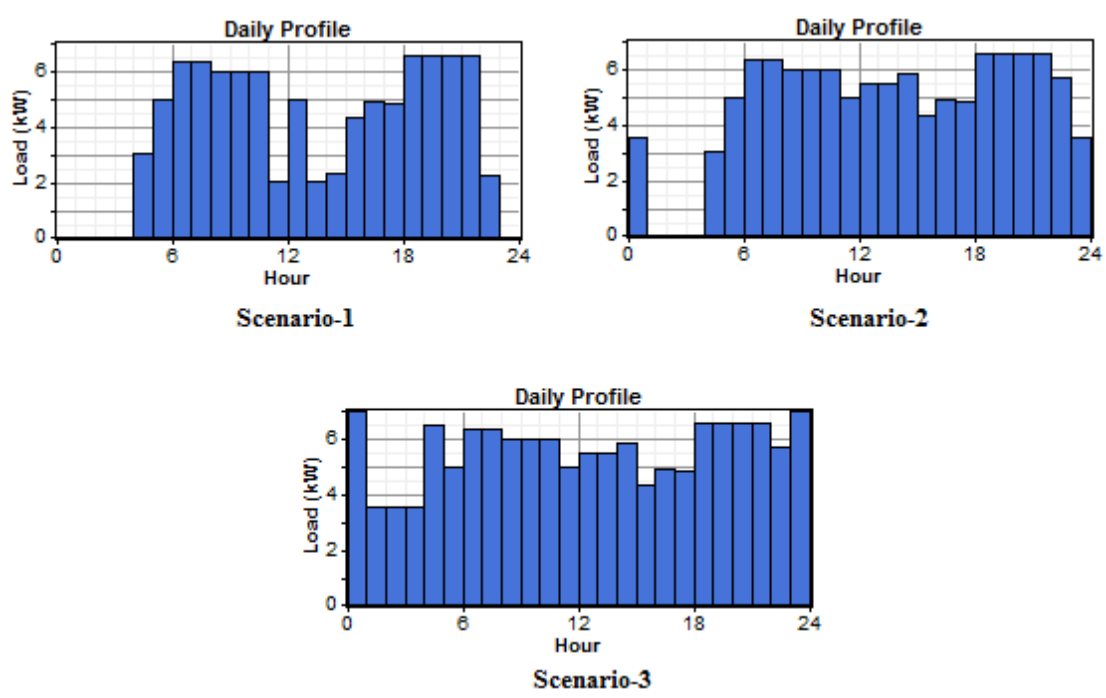

Figure 5: Daily load profiles estimated under different scenarios

In the first case, we are projecting that high-income households (four households are high income households) can afford water pumps, to irrigate their tea plantation field sites and there is a community hall, which we assume to be provided with lighting facilities and TV and a computer. Consideration of this load, in addition to the base load is projected to reduce the unit cost of electricity supplied from $0.072 \$ / \mathrm{kWh}$ in the base case to $0.063 \$ / \mathrm{kWh}$. The quantum of excess energy is too reduced to $40 \%$ of the total generation in this case. In the second scenario case, we introduced an additional productive load i.e. one tea garden machinery. In this case the unit cost of power production of the hydro plant is further reduced $0.052 \$ / \mathrm{kWh}$ and the excess electricity production goes down to $14611 \mathrm{kWh} /$ year. To improve the project viability, in the third scenario, we introduced additional tea garden machinery. The unit cost of electricity is further reduced to 0.044 $\$ / \mathrm{kWh}$ and the excess electricity production goes down to $7461 \mathrm{kWh} /$ year.

The link between increasing level of energy consumption and levelized cost of electricity is shown in Fig 6. The relationship indicates that with increasing load, there is a gradual decline in levelized unit cost of electricity. 


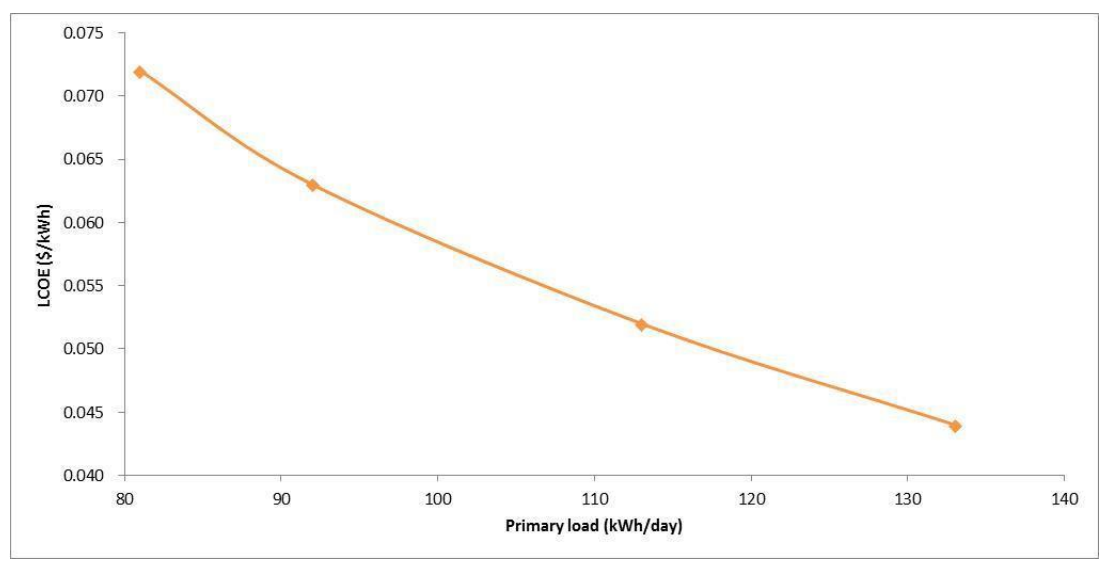

Figure 6: Levelized cost of generation of the plant w.r.t its primary load

The above case study clearly implies that there exists possibility of making use of generated excess electricity for various productive purposes. In addition to that, it also shows that micro-hydro projects are financially better options compared to solar based mini-grids, despite the fact that there have been dramatic fall in the solar module costs in recent years. Building on this case study as well as analysis, the next section offers some concluding remarks as well as a few policy recommendations.

\section{Conclusion and policy recommendations}

Renewable energy based off-grid systems played crucial role in providing energy access to remote and rural areas of Sri Lanka. Despite odds, the country has stridden a long way in providing basic minimum energy access to a large populace. This has been achieved with the help of strategic policy interventions and effective engagement of various stakeholders such as government institutions like PUSCL and SLSEA, donor agencies, project developers, and various financial intermediaries. The study reveals that the key leveraging points of success are robust community centric interventions, well designed credit systems, and strong capacity building initiatives. The comparative analysis between solar and micro-hydro projects for rural electrification unfolds that micro-hydro systems are cost-effective compared to solar systems, despite dramatic fall in solar prices in recent years. The techno-economic analysis of a running micro-hydro project further reveals there exist opportunity for more productive loads which could contribute to the betterment of local people. The key set of challenges encountered by the off-grid sector are issues related to legal, social as well as technical in nature. 
Several policy recommedations could be drawn from the Sri Lanka country case study, which could serve as an effective lesson for other countries of South Asia and also for other regions of the world. One of the key lessons is associated with the designing of off-grid programmes. It is important to conduct the exact needs assessment for designing of off-grid programmes. This is clearly evident in Sri Lanka case. The ESD programme, the first major programme on off-grid electrification in Sri Lanka, was designed keeping in consideration that 300,000 off-grid households were using car batteries for their basic electricity requirements. It clearly indicates that the designing of a particular programme/project must be built upon the existing needs and requirements. Second important lesson emerges from the policy and regulatory certainty for off-grid energy development in the country. The specific reference must be made to the SLSEA Act which says that the national grid can be extended to cover $97 \%$ of the population, and the remaining $3 \%$ can be covered by off-grid systems. In same vein, CEB has come up with the list of villages for off-grid projects. This is also reflected in the approval process set for the operationalization of micro-hydro projects. One of the initial approvals required for micro-hydro projects is to get the project certified by the Ceylon Electricity Board (CEB) that the prospective area lacks access to grid and hence requires an off-grid solution. In addition, CEB was also required to certify that the village under consideration will not receive grid electricity in the next five years. Third, it appears from the analysis of energy policy making in the country has experienced incremental policy learning. Policies are found to be modified and retrofitted depending on the changing needs and requirements. For instance, latest policy has emphasised the issue of tackling grid-interconnection matters - one of the burning issues worldwide related to off-grid energy development. In fact, Public Utilities Commission of Sri Lanka (PUCSL) has taken cognizance of it. It is also suggested that devising a feed-in-tariff mechanism through RPS for off-grid projects holds crucial at this juncture. This is because of the fact that without such mechanisms, off-taking of projects would not be feasible given that these projects are very small in size. Similar policy learning can also be observed in the matters of subsidy disbursement. Recent policy statement on subsidies has the provision that the amount of subsidies disbursed should decline over the life of the project with the premise that as the project moves closer to completion, systems providing electricity will also get cheaper.

These findings could be compared with similar studies carried out in other country contexts, largely in South Asia. For instance, while regulatory certainty issue is something which is while highly praiseworthy policy development in Sri Lanka, studies carried out in India (e.g. Palit and Bandyopadhyay, 2015) have identified persistence of such regulatory challenges for off-grid projects in Indian context. Similar evidences can be drawn related to grid-interconnection of off-grid projects. 
The challenges are almost similar in most of the South Asian countries. In Nepal, while pilot experiments have been carried out, nothing much has progressed. In India too, there have been patchy efforts done in this direction so far.

\section{Acknowledgement}

The authors acknowledge the funding support provided to the research project by the Engineering and Physical Sciences Research Council (EPSRC) and Department for International Development (DFID) research grant (EP/G063826/2) from the Research Council, United Kingdom (RCUK) Energy Program.

\section{References}

1. ADB, Assessment of Power Sector Reforms in Sri Lanka, 2015.

2. ADB and UNDP. $100 \%$ electricity generation through renewable energy by 2050: Assessment of Sri Lanka's power sector, 2017.

3. AFREPREN. The role of feed-in tariff policy in renewable energy development in developing countries: A toolkit for parliamentarians. Energy Environment and Development Network for Africa; 2009.

4. Amarawickrama H A, Hunt L C. Sri Lankan electricity supply industry: A critique of proposed reforms. Surrey Energy Economics Centre (SEEC), University of Surrey; 2004.

5. ESMAP. Mini-grids and the arrival of the main grid: Lessons form Cambodia, Sri Lanka, and Indonesia, 2018.

6. Ferdinando M M C, Gunawardana R J. Electricity generation from renewable energy in Sri Lanka: Future directions. Colombo: Ceylon Electricity Board (CEB); 2008.

7. Flavin C, Aeck M H. Energy for development: The potential role of renewable energy in meeting Millennium Development Goals (MDGs). REN21, the Worldwatch Institute; 2006.

8. Holland R, Perera L, Sanchez T, Wilkinson R. Decentralised rural electrification: The critical success factors. Colombo: Intermediate Technology Development Group (ITDG); 2010.

9. Kohle M. Techno-economic optimum sizing of hybrid renewable energy system: rural electrification in Sri Lanka; 2013.

10. Nieusma D. Challenging knowledge hierarchies: working toward sustainable development in Sri Lanka's energy sector. Sustainability: Science, Practice and Policy 2007;3:1-13.

11. Nouni M R, Mullick S C, Kandpal T C. Techno- economics of micro-hydro projects for decentralized power supply in India. Energy Policy 2006;34:1161-1174. 
12. Palit D, Chaurey A. Off-grid electrification experience in South Asia: Status and best practices. Working Paper Series 01. OASYS South Asia Research Project; 2011.

13. Palit D, Bandoadhyay K. Regulating off-gird electricity delivery. Economic and Political Weekly 2015; 50 (10).

14. Palit D, Malhotra R, Kumar A. Sustainable model for financial viability of decentralized biomass gasifier based power projects. Energy Policy 2012;39:4893-4901.

15. PUCSL. Annual report on achievement of renewable energy targets in Sri Lanka - 2011. Colombo: Public Utilities Commission of Sri Lanka (PUCSL); 2012.

16. PUCSL. Grid interconnection mechanisms for off-grid electricity schemes. Colombo: Public Utilities Commission of Sri Lanka (PUCSL); 2013.

17. RERED. Renewable Energy for Rural Economic Development (RERED) Project. Government of Sri Lanka; 2013.

Available at: http://www.energyservices.lk/statistics/esd_rered.htm

18. Salih N. Renewable for rural electrification in Sri Lanka. MS Thesis. Stockholm: KTH School of Industrial Engineering and Management; 2012.

19. SLSEA. Renewable energy technologies: Solar energy. Sri Lanka Sustainable Energy Authority (SLSEA), Government of Sri Lanka; 2013.

20. Subasinghe, K. Grid interconnection of off-grid community based projects. Accessed @ https://energypedia.info/images/f/f2/Grid_Interconnection___Sri_Lanka.pdf

21. Sugathapala A G T. Policy analysis to identify the barriers to the promotion of bioenergy technologies in Sri Lanka. Energy for Sustainable Development 2002 ;3:50-58.

22. The World Bank. Designing sustainable off-grid rural electrification projects: Principles and practices. Washington DC: The World Bank; 2006.

23. The World Bank. Per capita energy consumption - 2019. Washington DC: The World Bank; 2019.

24. Wickramasinghe H. Off-grid village hydro schemes in Sri Lanka: A success story. Presentation delivered at Sri Lanka Sustainable Energy Authority (SLSEA), Colombo; 2013.

\section{Annexure}

Annexure I: Financial details of Maha Dola village micro-hydro project

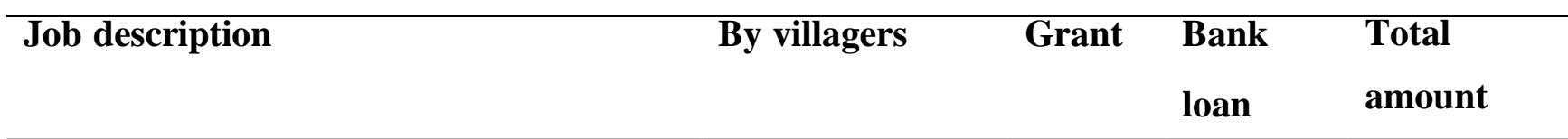




\begin{tabular}{|c|c|c|c|c|c|}
\hline & Labour & Cash & Cash & Cash & \\
\hline Weir, intake, headrace & 25000 & 75000 & - & - & 100000 \\
\hline Forebay tank & 10000 & 35000 & - & - & 45000 \\
\hline Power house building & 10000 & 65000 & - & - & 75000 \\
\hline Penstock pipe fittings \& PVC gum & 40000 & - & 110000 & 340000 & 490000 \\
\hline Turbine $(7.5 \mathrm{~kW})$ & - & - & 150000 & 125000 & 275000 \\
\hline $\begin{array}{l}\text { Induction motor (as generator } 7.5 \mathrm{~kW} \text {, } \\
1450 \mathrm{rpm} \text { ) }\end{array}$ & - & - & 35000 & 15000 & 50000 \\
\hline $\begin{array}{l}\text { I.G.C. unit, control panel \& switchgear } \\
\text { Ballets load discharging unit }\end{array}$ & - & - & $\begin{array}{l}75000 \\
20000\end{array}$ & $\begin{array}{l}75000 \\
10000\end{array}$ & $\begin{array}{l}150000 \\
30000\end{array}$ \\
\hline $\begin{array}{l}\text { Distribution, SVC cable D-iron, insulators } \\
\& \text { surge arrestors }\end{array}$ & 50000 & 120000 & 60000 & 280000 & 510000 \\
\hline Wooden poles & 25000 & 75000 & - & - & 100000 \\
\hline Transport & - & 10000 & - & - & 10000 \\
\hline Contingencies & - & 10000 & - & - & 10000 \\
\hline \multirow[t]{2}{*}{ Sub total } & 160000 & 390000 & & & \\
\hline & 550000 & & 450000 & 845000 & \\
\hline \multirow[t]{2}{*}{ Percentage total } & 29.81 & & 24.39 & $45.80 \%$ & \\
\hline & $\%$ & & $\%$ & & \\
\hline Total cost of the project & & & & & 1845000 \\
\hline
\end{tabular}

Annexure II: Number of wet days in a month over the last decade in Kavittikanda

$\begin{array}{llllllllllllll}\text { Month } & \mathbf{1 9 9 7} & \mathbf{1 9 9 8} & \mathbf{1 9 9 9} & \mathbf{2 0 0 0} & \mathbf{2 0 0 1} & \mathbf{2 0 0 2} & \mathbf{2 0 0 3} & \mathbf{2 0 0 4} & \mathbf{2 0 0 5} & \mathbf{2 0 0 6} & \mathbf{2 0 0 7} & \begin{array}{c}\text { Total } \\ \text { Average } \\ \text { decimal }\end{array} \\ \text { January } & 1 & 10 & 7 & 8 & 14 & 7 & 8 & 6 & 12 & 13 & 5 & 90 & 9 \\ \text { February } & 5 & 7 & 13 & 18 & 9 & 5 & 6 & 17 & 3 & 11 & 1 & 90 & 9 \\ \text { March } & 9 & 8 & 5 & 12 & 7 & 11 & 16 & 16 & 12 & 10 & 5 & 102 & 10 \\ \text { April } & 14 & 12 & 15 & 8 & 18 & 14 & 14 & 24 & 14 & 9 & 23 & 151 & 15 \\ \text { May } & 15 & 18 & 22 & 12 & 22 & 18 & 16 & 27 & 15 & 18 & 15 & 183 & 18 \\ \text { June } & 10 & 23 & 18 & 20 & 19 & 12 & 24 & 21 & 24 & 15 & 21 & 197 & 20 \\ \text { July } & 25 & 22 & 11 & 11 & 19 & 19 & 26 & 25 & 25 & 15 & 25 & 198 & 20 \\ \text { August } & 17 & 25 & 23 & 23 & 9 & 15 & 24 & 14 & 13 & 24 & 17 & 187 & 19\end{array}$




\begin{tabular}{|c|c|c|c|c|c|c|c|c|c|c|c|c|c|c|}
\hline & September & 19 & 21 & 14 & 20 & 15 & 14 & 25 & 20 & 17 & 17 & 23 & 186 & 19 \\
\hline$\frac{1}{2}$ & October & 22 & 18 & 19 & 20 & 22 & 24 & 23 & 25 & 25 & 23 & 20 & 219 & 22 \\
\hline $\begin{array}{l}3 \\
4\end{array}$ & November & 16 & 14 & 12 & 15 & 15 & 23 & 23 & 13 & 22 & 25 & 6 & 168 & 17 \\
\hline $\begin{array}{l}5 \\
6\end{array}$ & December & 11 & 14 & 10 & 11 & 9 & 11 & 9 & 14 & 11 & 16 & 12 & 117 & 12 \\
\hline 7 & Total & 164 & 192 & 169 & 178 & 178 & 214 & 214 & 222 & 193 & 196 & 173 & 1888 & 190 \\
\hline
\end{tabular}

\section{Annexure III: List of stakeholders interviewed}

\begin{tabular}{ll}
\hline Name & Organization \\
Ms Sushara Vidyasagara & Commercial Bank of Ceylon Ltd. \\
Dr Thusitha Sugathapala & Sri Lanka Sustainable Energy Authority (SLSEA) \\
Mr M. M. R. Pathmasiri & Sri Lanka Sustainable Energy Authority (SLSEA) \\
Mr Harsha Wickramasighe & Sri Lanka Sustainable Energy Authority (SLSEA) \\
Mr Gamini Herath & Public Utilities Commission of Sri Lanka (PUCSL) \\
Mr Nalin Edirisinghe & Public Utilities Commission of Sri Lanka (PUCSL) \\
Ms Dilunika Jayasinghe & Hatton National Bank (HNB) \\
Ms Gunaseeli Jayasoma, & JLanka Technologies Private Limited \\
Mr Sampath Fonseka & Ceylon Electricity Board (CEB) \\
Mr Damitha Samarakoon & Practical Action \\
Mr P. C. Hettiaratchi & Systems Engineer \\
Mr B. R. O. Fernando & The Gideon International \\
Prof. Anoja Wickramasinghe & University of Peradeniya \\
Mr Dissanayake & Lankan Electricity Company Private Limited (LECO) \\
Mr K. H. L. C. K. Kariyawasam & Project Developer \\
Mr Ranishka Wimalasena & Asian Development Bank (ADB) \\
Mr Ravindra S. Ariyawickrama & Sarvodaya Sri Lanka \\
Mr Sunil & Sarvodaya Sri Lanka \\
Mr Kapila Subasinghe & DFCC Bank \\
\hline
\end{tabular}

